\title{
The Role of the Holy Spirit in Human Deification
}

\author{
fr. Marek Ławreszuk \\ Katedra Teologii Prawosławnej \\ Uniwersytetu w Białymstoku \\ Polska \\ xmlawreszuk@gmail.com
}

Ks. Marek Ławreszuk, Rola Ducha Świętego w przebóstwieniu człowieka, Elpis, 18 2016: 21-26.

\begin{abstract}
This article focuses on introducing the teaching on the Holy Spirit and His relation with man. This article's main objective is to demonstrate the role of the Holy Spirit in human deification (theosis) and the experience of human relations with the Holy Spirit in Orthodox theology. When speaking of the gifts of the Holy Spirit and His grace, Orthodox theology also speaks of the kenosis of the Third Person of the Holy Trinity and human participation in the Holy Spirit.

Streszczenie: Niniejszy artykuł skupia się na przedstawieniu nauki o Duchu Świętym w Jego relacji z człowiekiem. Podstawowym celem jest ukazanie roli Ducha Świętego w przebóstwieniu człowieka i doświadczenia relacji człowieka z Duchem Świętym w teologii prawosławnej. Mówiąc o darach Ducha Świętego i Jego łasce, prawosławna teologia mówi zarówno o kenozie Trzeciej Osoby Trójcy Świętej, jak i o osiągalnym dla człowieka uczestnictwie w Duchu Świętym.
\end{abstract}

Keywords: Holy Spirit, deification, orthodox theology, pneumatology, anthropology

Słowa kluczowe: Święty Duch, przebóstwienie, teologia prawosławna, pneumatologia, antropologia

\section{Introduction}

Bishop Jerzy Wagner's statement that "Orthodoxy does not lay claim to possessing a special kind of understanding of the Holy Spirit" (Wager, 1974, pg. 214) serves as the inspiration for the analysis conducted in this article. Fr. Henryk Paprocki's controversial comment that Wagner's statement is at the same time both legitimate and incomplete prompts us to a deeper analysis of Orthodox pneumatology. Moreover, the frequent reference to the activity of the Holy Spirit in Orthodox ecclesiology (Afanasyev, 2002, pg. 5-7) and anthropology (Leśniewski, 2014, pg. 80-81), requires us to consider the significance and role of the Holy Spirit in the life of the Church and its members. The topic's limitation requires us to reflect on the relation of the Holy Spirit and humanity. If, in this context, we regard Wagner's statement, it should be stated that, on the one hand, he correctly limited Orthodox pneumatology to the Symbol of Faith, while on the other hand, he treated the witness of the Church Fathers in an incomplete manner, as he limited them entirely to the period of the undivided Church. In Fr. Paprocki's opinion, "such a manner of setting the issue of Orthodox pneumatology should be regarded as a far too limited experience of the Holy Spirit in the Orthodox Church" (Paprocki, 2012, pg. 15). It is precisely in this second period in the history of the Orthodox Church, the time after the ecclesiastical division of East and West, that the Orthodox teaching on the role of the Holy Spirit in human deification is fully discovered.

\section{The Era of the Undivided Church}

The Descent of the Holy Spirit on the Day of Pentecost changes His form of activity in human life. In so far as in the Old Testament, after the fall of man, the Holy Spirit operates outside of nature, in the New Testament, He descends into human nature and starts to operate internally (Evdokimov, 1964, pg. 299). Two main moments of change occur during the Baptism of the Lord, when the Holy Spirit descends on Jesus, and on the Day of Pentecost. The descent of the Comforter is foretold by the Saviour and takes place as the next essential element of God's saving act. As Lossky points out, "Pentecost appears therefore as the final goal, as the final crowning of the economy of God on earth" (Lossky, 1989). For this reason, rejecting the gift of God and the act of salving help is, in the words of the Saviour, a sin which will never be forgiven (Mt 12:31). This rejection is a sin, because the descent of the Holy Spirit is an essential step in repentance: "no one can enter the kingdom of God without being born of water and Spirit" (Jn 3:5).

The early Church presented the foundation of dogmatic teaching and defined the role of the Holy Spirit in the salvation of man. This foundation of the undivided Church is concentrated in the Nicene-Constantinopolitan Creed and is later supplemented in the texts of the dogmatic statements of the Seven Ecumenical Councils, the Photian Synod of Constantinople of 861 and 879 and the Councils of Constantinople of 1341 and 1351 concerning Palamism (Evdokimov, 1964, pg. 199). Out of these indisputable dogmas, all of the decisions aside from the canons of the coun- 
cils dealing with Palamism in the $14^{\text {th }}$ century, are made in the era of the undivided Church.

A proper understanding of the dogmatic foundation of pneumatology is found in the statement that "their intent was not to provide a clear explanation of the nature of the Holy Spirit, as this is impossible, but only to list the theological errors relating to Him" (Paprocki, 2012, pg. 13).

The dogmatized pneumatological teaching of the Church appeared for the first time in the articles of the Symbol of Faith, which came into being at the Second Ecumenical Council. Article one of the Second Ecumenical Council became a carrier of the dogmatic statement, which arose as a result of the despite with the "Combaters against the Spirit" (Pneumatomachi), who refused to acknowledge the consubstantiality of the Holy Spirit with the Father and therefore rejected the divinity of the Holy Spirit. The dogmatic decision thus became an apology of the true faith, and their development appeared later in the works of Fathers such as St. Athanasius the Great, St. Gregory the Theologian and St. Basil the Great. For this reason, St. Basil focuses primarily on "establishing the character of the Third Hypostasis of the Holy Trinity in the framework of Neo-Nicaean Orthodoxy in "On the Holy Spirit" (Paprocki, 2012, pg. 13).

The development of pneumatology in the first millennium mainly concentrated on the Trinitarian aspect, that is, on the mutual relations of the Holy Spirit with God the Father and the Word. The period of pneumatological discussions and the East and West's dispute over the Filioque also focused on this. Theologians accented the fundamental difference between the being of the Holy Trinity and the mission of the Son and the Holy Spirit defined in time (Lossky, 1989). St. Photios, Patriarch of Constantinople, in his work "Mystagogy of the Holy Spirit" also concentrates on the polemic regarding the doctrine of the Filioque and the question of the procession of the Holy Spirit (Paprocki, 2012, pg. 14). At times, even much later official documents of the Orthodox Church were limited in regards to questions of pneumatology to the problem of the Filioque and defining the relation of the Persons of the Holy Trinity ( $\mathrm{Pa}-$ procki, 2012, pg. 14).

\section{Discovering the Role of the Holy Spirit in Human Deification}

It took a long process, starting in the early years of Christianity, to move from a dogmatic definition of the Holy Spirit to describing His relation with man.

St. Gregory of Nyssa reflects on the revelation of the Third Person of the Holy Trinity. It is only the Holy Spirit that is not revealed in another Divine Person. He also does not come in His own name, "but in the name of the Son, to give witness to the Son" (Lossky, 1989, pg. 142).

St. Gregory of Nazianus points out that the revelation of the Holy Spirit is more dynamic than the revelation of the Divine Logos: "The Old Testament was a clear revelation of the Father, and in a hidden sense, of the Son. The New Testament revealed the Son and only suggested the thought of the divinity of the Holy Spirit. Today, however, the Holy Spirit lives among us and allows Himself be known more clearly (Lossky, 1989, pg. 143-144).

St. Symeon the New Theologian, in reference to the words of St. Gregory of Nazianus, accents the apophatic nature of the Holy Spirit in his hymnography. Both teachers also emphasise the hidden revelation of the Holy Spirit (Lossky, 1989, pg. 142-143).

The development of Orthodox dogmatic thought on the Holy Spirit distinguishes the unrevealed Divine Person and the gift, which He gives to people. This dogmatic development is based on the promise of the Saviour to send the Divine gifts (Jn 16:14-15).

The ascetic writings of St. Symeon the New Theologian, which through apophaticism of the Spirit moved on to search for the signs of the revelation of the Holy Spirit and His gifts, and is very valuable for Orthodox dogmatic thought (Paprocki, 2012, pg. 14). St. Symeon becomes an inspiration for Orthodox mysticism and exploration of the gifts of the Holy Spirit, later undertaken by, among others, St. Paisius Velichkovsky, St. Seraphim of Sarov and the monks of the Optina Monastery. We cannot state, however, that he is the first Father of the Church that directs pneumatology towards an exploration of the signs of the activity of the Holy Spirit. His several predecessors, the previously mentioned St. Gregory of Nazianus, St. Basil and St. Anthansius the Great, and St. John of Damascus also accented the presence of the Holy Spirit in all the signs of God's grace. In as much as St. Basil the Great stated that there is no gift given to creation in which the Holy Spirit is not present, St. John of Damascus attempts to define these gifts in the various terms: the source of wisdom, life, holiness, Fullness, Creator, Master, Initiator, Almighty, Ruler, Deifying, The Self-Imparting (Lossky, 1989, pg. 145).

In this manner, the Holy Spirit enters into relation with man by giving him the gift that is common for the Holy Trinity - Divinity. He gives this gift to people in the Church by means of making them "participants of the divine nature" (Lossky, 1989, pg. 144).

The question of the kinds of the Holy Spirit's gifts has provided us with an answer that we can divide into two groups. The first, in search of the gifts of the Holy Spirit, is inspired by the words recorded in the Book of Isaiah (Isa 11:2) which mentions seven spirits: wisdom, understanding, council, might, knowledge and the fear of the Lord (Lossky, 1989, pg. 144-145). The second, characteristic for Orthodox theology, does not attempt to limit the grace of the Holy Spirit to the abovementioned seven spirits: "The wind blows where it chooses, and you hear the sound of it, but you do not know where it comes from or where it goes. So it is with everyone who is born of the Spirit (Jn 3:8)" (Paprocki, 2012, pg. 17). Orthodox thought connects the gifts mentioned in the Book of Isaiah with the grace of deification, which defines the richness of the divine nature, which imparts itself to people.

The deifying grace is Divinity, "which goes outside its being and imparts itself" and also "the nature of God, in which one participates in energies" (Lossky, 1989, pg. 145). 
Deification was also defined by the Holy Fathers as "Divine adoption," "becoming like God," and "transformation in God" (Alfeyev, 2009, pg. 248).

The revelation of the Holy Spirit occurs in accordance with the words of Christ: "The Advocate, the Holy Spirit, whom the Father will send in my name" (Jn 14:26). The mission of the Holy Spirit is a mission for the Church since one must first become a Christian and accept Christ in order to then receive the Holy Spirit. The Church does not exist without Christ, and without accepting Him as the Head and Son of God, recapitulation does not take place and the Holy Spirit also cannot appear. The saving work of Christ, in accordance with St. Irenaeus's favourite term, recapitulates human nature in His hypostasis. Christ becomes the Head of the Church and hypostasis of the Body comprised of all who wish to be together with Him. The faithful do not blend into the Divine Person of Christ. The hypostasis of this united nature still remains. By forming one nature in Christ, the Church as the new body of humanity contains within itself many human hypostases.

If Christ's work recapitulates human nature in His hypostasis, then the activity of the Holy Spirit applies not to human nature, but individually to every person. (Lossky, 1989, pg. 148).

The Hesychast movement, which originated in the monasteries of Mount Athos in the $14^{\text {th }}$ century and later developed in the Balkans and Slavic lands, was an important step in the development of pneumatology and discovery of the relation of the Holy Spirit with man. The essence of this movement has had such great significance that Vladimir Lossky defined the period from the $10^{\text {th }}$ century to our times as "the pneumatological cycle" (Paprocki, 2012, pg. 15). ${ }^{1}$ St. Gregory Palamas's apology of the Hesychast concept in the $14^{\text {th }}$ century and the decisions of the Constantinopolitan Councils in 1341 and 1351 introduced the teaching about the role of the Holy Spirit in human deification into the official teaching of the Orthodox Church (Lossky, 1983, pg. 156; Paprocki, 2012, pg. 15).

The Hesychast concept is a study of "seeing God." St. Gregory Palamas, who presented the Divine nature as unknowable, taught that it is at the same time knowable by Its natural energies: "Illumination or deification and deifying grace is not the essence (ousia) but Divine energy [...] the power and activity of the Holy Spirit" (Lossky, 1983, pg. 157 trans. MŁ). Hesychasts, indicating the orthodoxy of their teaching, presented evidence from Holy Scripture and the writings of the Holy Fathers that proved their concept. Both Holy Scripture and the Holy Fathers present God as invisible and inaccessible, but simultaneously also clearly speak of the possibility of seeing Him (Alfeyev, 2009, pg. 241-242). In the Old Testament, God is invisible and unknowable, but at the same time, we hear how Job says "my eyes shall be-

\footnotetext{
The Pneumatological cycle began in the Church after the Christological cycle that is associated with the defining of the teaching of the Church concerning the Person of Jesus Christ and historical Christological disputes. In Lossky's opinion, the Christological cycle, concluded in the year 843 in the Triumph of Orthodoxy and victory over iconoclasm (Paprocki, 2012, pg. 15-16).
}

hold, and not another (Job 19:27)2, and "now my eye sees you" (Job 42:5). The New Testament confirms the possibility of seeing God in the words of Christ in the Beatitudes (Mt 5:8), in the words of the Apostles John and Paul (1 Jn 3:2) and in St. Paul's Letter to the Corinthians (1 Cor 13:12). Above all, the words of Christ were fundamental for Hesychasts and St. Symeon the New Theologian referred to them in his defence of Hesychast thought. The Saviour clearly states that "Whoever has seen me has seen the Father" (Jn 14:19). St. Symeon unequivocally points out that the words of Christ do not speak of seeing his flesh, "but of the revelation of His Divinity” (Lossky, 1983, pg. 14-18).

Hesychasts proclaimed that God can be seen. In particular, St. Gregory Palamas, focusing on the question of seeing God, refutes the contradictory statement that God cannot be seen. He bases his argument on the deference between God's essence and energy. He defines God's energies as His activity: "God's essence becomes accessible not in itself, but in its energies" (Alfeyev, 2009, pg. 243). This distinction between essence and energy was accepted by the councils in the $14^{\text {th }}$ century as a dogmatic expression which corresponds with the teaching of Pseudo-Dionysius the Areopagite, the Cappadocian Fathers, St. Maximus the Confessor and St. John of Damascus (Lossky, 1983, pg. 157158). Hesychasm is chiefly pursuit to know the unknowable God in His operations. Operation, that is, energy can be defined as grace or gift. Moses's vision (Ex 33:18-20; $22-23$ ) is a contemplation of God's energies and God's inaccessible essence. According to the definition set out by the Constantinopolitan Council held in 1351, this energy was defined as "Divine and uncreated grace," "indivisible from the essence of the Holy Trinity" (Lossky, 1983, pg. 158). In accordance with the teaching of St. Maximus the Confessor, this energy is the mystical experience of grace, by which God makes Himself known to those who enter into unity with Him by means of exceeding the barrier of materiality (Lossky, 1983, pg. 160).

The operation of the Holy Spirit in the life of man must be presented in light of God's act of creation. Creating man in "the image and likeness of God" is completed in the saving act of the New Testament. Through Christ, the image of God becomes one image proper for the common human nature. The operation of Holy Spirit is the possibility of realizing the likeness of God in every person created in the image of God: "One imparts His hypostasis to nature and the Second gives His divinity to people" (Lossky, 1989, pg. 148). The operation of the Holy Spirit is therefore connected both with the act of creation and act of salvation. The work of Christ and the Holy Spirit are inseparable. Christ unites in His mystical body through the Holy Spirit, and the Holy Spirit imparts Himself to people through Christ.

Lossky reminds us that the gift of the Holy Spirit to the Church is described in the New Testament twice. In the Gospel of John, we read of how Christ breathed on His Apostles on the day of His Resurrection (Jn 20:19-23) while

2 Quotations from Holy Scripture are taken from the New Revised Standard Version Bible (Nashville: Thomas Nelson Publishers, 1989). 
the Acts of the Apostles depicts the personal coming of the Holy Spirit on the Day of Pentecost (Acts 2:1-5) (Lossky, 1989, pg. 148-149). Bulgakov also speaks of another revelation of the Holy Spirit in the person of the Mother of God, who was called Pneumatphora, that is the Bearer of the Spirit and "a living intermediator of the Holy Spirit" (Bulgakov, 1992, pg. 200-201). Provided that the first breathing of the Spirit is compared to the grace sent on the Apostles symbolizing a new mystical body, the second event leads to the imparting of the Holy Spirit to particular people by marking them with the seal of a personal bond with the Trinity. The Fathers describe this descent of the Holy Spirit as the kenosis of the Holy Spirit (Lossky, 1989, pg. 150). Kenosis conceals the Divine Person of the Spirit, leaving Him unrevealed, but simultaneously hidden in the gift. This event reflects the kenosis of the Son of God, in which the Person is revealed, while His divinity was hidden "in the form of a slave." The kenosis of the Holy Spirit therefore reveals gifts while hiding the divinity of the giver. This kenosis would never be possible if the hypostasis of the Holy Spirit was dependant on the hypostasis of the Son. In that case, Pentecost would be an operation of the Holy Spirit as a helper of Christ, and one's pursuit of salvation could concentrate on "a way to the unity of the soul with Christ through the Holy Spirit" (Lossky, 1989, pg. 151).

In Orthodox theology, the kenosis of the Holy Spirit always differentiates His Person from uncreated grace which He imparts to people (Lossky, 1989, pg. 153).

The revelation of St. Seraphim of Sarov concentrated not on describing the gifts of the Holy Spirit, but rather embarked on a search for them. The description "acquiring the Holy Spirit" has become the objective of human spiritual development (Paprocki, 2012, pg. 17). In Orthodox theology, we see the call to search for the unrevealed divinity of the Holy Spirit through gifts and grace. According to the words of St. Gregory Palamas, the one who participates in God's grace, becomes united with light and "becomes in a certain manner light" (Lossky, 1983, pg. 164). In these words the goal of our life, which is well-known from the words of St. Seraphim is revealed: striving for deification as the natural way of man to God.

Hesachysm should not be limited to man's individual experience. In a particular way, it is manifested, as is the case with all the works of the Holy Spirit, in liturgical and communal experience. In a strict understanding, the role of the Holy Spirit in a person's life is individual and applies to every person. The grace of the Holy Spirit, however, leads to Christ and the community of divine and human nature. The grace of the Holy Spirit is given to people in the Sacraments of Baptism and Chrismation. Operating in both sacraments, the Comforter recreates human nature by cleansing and uniting it with Christ, and also by granting the divine grace and common energy of the Holy Trinity (Lossky, 1989, pg. 151).

The Holy Spirit lives in man, thus making him a dwelling place of the Holy Trinity, which is after all inseparable. The descent does not reveal the Spirit Himself, but His grace. The kenosis of the Holy Spirit takes place in every person as
St. Symeon the New Theologian wrote, grace cannot be hidden in a person: "If anyone believes that all believers have received and have the Holy Spirit unconsciously, or know nothing of Him, blasphemes by treating the words of Christ, which say that the Spirit is 'a spring of water gushing up to eternal life' as a lie (Jn 4:14) [...] If the spring is within us, then the river flowing from it must be essentially seem for those who have eyes to see" (Lossky, 1989, pg. 153).

The Holy Spirit lives in man by means of the Sacrament of Chrismation. The sacramental "seal" is a gift (dorea), although in the prayers read during the service and in other prayers of the Church referring to the grace of the Holy Spirit, plural form is used when speaking of gifts ( $h a-$ rimata) (Schmemann, 2000, pg. 78). The diversity of the gifts of grace are associated with the reason for which they are imparted to us. Since the objective is deification, the gifts transform us. This is a symbolically shown in the sacramental seals that touch each of our senses: sight, hearing, speaking, touch and smell.

The grace of the Holy Spirit is uncreated and divine in nature. When granted to created beings, the deifies them. This diametrically differs from the actions of God's will in the Old Testament, which affected the human soul as an "external cause" (Lossky, 1989, pg. 154). The kenosis of the Holy Spirit identifies Him with human people, but also leaves Him at the same time independent. This kenosis leads to removing the Holy Spirit from created people, to whom He imparts. (Lossky, 1989, pg. 154).

The role of the Holy Spirit in human deification is not therefore an external activity, but an internal operation. The main task is to strive to accept His grace, which appears in man. As far as one remains in the will of God, grace becomes his own will. For this reason, in the sacrament of the Holy Spirit, grace is defined as "a royal anointing," which rests on Christ, and on all Christians who are called to rule in the age to come. The individual effect of the Holy Spirit on man allows him to know God by that operation. This might be defined as a vision or revelation, as in the case of the Apostle Paul, who in the Letter to the Corinthians describes how he was "caught up to the third heaven" (2 Cor 12:1-4). This vision or revelation by the grace of the Holy Spirit allows us "to see God." The Apostle Paul does not say anything about this vision, besides stating that "no mortal is permitted to repeat" it (2 Cor 12:4). St. Symeon the New Theologian conveys this vision of God in liturgical poetry, where God is shown as light: "With wonder and fear I perceive Christ. Opening the heavens, He descends from there, with the Father revealing Himself to me with the Divine Spirit, He is one, but in Three Persons: Three in complete unity, thrice-holy radiance in three divine suns" (cited in Alfeyev, 2009, pg. 245-146). For Hesychasts, God is uncreated light, the same light that the New Testament mentions as overwhelming the Apostles on Mount Tabor and that which Moses saw on Mount Sinai in the Old Testament.

Barlaam, who accused the Hesychasts of Messalianism, errored in the fact that he identified the experience of the uncreated light of the Hesychasts with material vision of God. This error extended further - Barlaam understood 
the experience of the light as direct contact with the Divine nature. However, the teaching of the Hesychasts could be understood only in the context of grace, which is perceivable, in contrast to the kenotic Spirit (Lossky, 1983, pg. 154).

Deification is an operation of the Holy Spirit, which requires human acceptance, and also human striving, which St. Seraphim of Sarov described as "acquiring the Holy Spirit" (Osipov, 2011, pg. 203).

The grace of the Holy Spirit reveals itself therefore mainly in the lives of those deified and its chief image, in Lossky's opinion, is above all "the great number of saints" (Lossky, 1989, pg. 154). The aim of deification is therefore is also the goal of the grace of the Holy Spirit's activity, which is "achieving full communion with God, of which the highest possible level is unity with the Divine" (Alfeyev, 2009, pg. 247). Most often, this fullness is described in Holy Scripture with the words love and joy. The Saviour said: "I have said these things to you so that my joy may be in you, and that you joy may be complete" (Jn 15:11). When naming the gifts of the Holy Spirit, the Apostle Paul spoke of love, joy and peace (Gal 5:22). In this light, Hymn of Love (1 Cor 13:1-13) should be read. Professor Osipov points out the role of the Holy Spirit in the life of man, and all of the gifts and grace concentrate in one instruction of "the greatest good, that is love" (Osipov, 2011, pg. 202).

The role of the Holy Spirit is therefore an internal activity of His grace and manifests itself in the sacraments, prayer and in all human good works. Evdokimov states that "in the heart of every sacrament is found an proper operation of Pentecost, a descent of the Holy Spirit" (Evdomikov, 1964, pg. 266). The sacraments cannot be limited to the Latin number of seven sacraments. Broadly speaking, “ everything in the life of a Christian is related to the Church and therefore sacramental [...] everything is a charisma, service and gift" (Evdomikov, 1964, pg. 281). The grace of the Holy Spirit supports and guides those who fulfill the will of God, everywhere. In relation to the words of St. Paul, "to each is given the manifestation of the Spirit for the common good" (1 Cor 12:7), and we must bear in mind that it is for this reason that the Orthodox Church begins all prayers of intention with calling on the Holy Spirit to "come and abide in us."

The grace of the Holy Spirit is also called upon to realize the Christian calling applicable to both the faithful and their pastors. In the first Prayer of the Faithful in the Liturgy of St. John Chrysostom, we see the role of the Holy Spirit in the transformation of those presiding over the sacrament: "enable us also, who Thou hast placed in this Thy service, by the power of Thy Holy Spirit [...], call upon Thee" (The Divine Liturgy of St. John Chrysostom, 2001, pg. 58-59).

The most important and fundamental communal experience of the Holy Spirit in the Orthodox Church is the Eucharist. In order to understand the Orthodox Epiclesis, we must bear in mind that the Risen Body of Christ is a spiritual body, and thus the Apostle Paul could write: "The last Adam became a life-giving spirit" (Paprocki, 2012, pg. 18-19). The Epiclesis constitutes an Orthodox confession of faith concerning the "role of the Holy Spirit in the economy of salvation and in Trinitarian equilibrium. Christ the Word speaks the Words of Institution and the Epiclesis asks the Father that He send the Holy Spirit as a sanctifying power on the gifts and the whole Church" (Evdomikov, 1964, pg. 266).

Orthodox theology emphasises that the decent of the Holy Spirit, which occurs during the Eucharistic service, applies to both the Eucharistic gifts and the faithful (Ławreszuk, 2014b, pg. 125). Calling upon the Holy Spirit in the Divine Liturgy of St. John Chrysostom clearly states: "we pray Thee and call upon Thee, that [...] Thy Holy Spirit may come upon us and upon the gifts now offered" (Divine Liturgy of St. John Chrysostom, 2001, pg. 81). Likewise, in the Prayer of the Prokomedia of the Divine Liturgy of St. John Chrysostom, after placing the gifts on the altar, we hear the words: "Make us worthy [...] that the good spirit of Thy grace may dwell upon us and upon these Gifts here offered, and upon all Thy people" (Divine Liturgy of St. John Chrysostom, 2001, pg. 72). Even in the special Anaphora of the "Apostolic Tradition", in which a traditional Epiclesis is not found, but a so called rising Epiclesis (восходящий епиклесис) (Алымов, pg. 46) appears with a prayer directed to God the Father, which we can explain in the following manner: "The Father accepts the offering of the Son through the operation of the Holy Spirit" (Eawreszuk, 2014a, pg. 34).

Based on the words of the prayer of the Epiclesis, Orthodox theologians speaks of the operation of the Holy Spirit, through whose Parousia Christ's Parousia is performed in the Eucharist and a "complete pneumatisation of the nature of the Saviour continues in those who participate in His 'Most Holy Body"' (Evdomikov, 1964, pg. 267).

While speaking of Parousia, we must indicate the role of the Holy Spirit in the Last Judgement. Sergei Bulgakov emphasises that just as the creation of the world and man took place by the operation of each member of the Holy Trinity, so also the end of the world, the Last Judgement, "will also take place by the operation of the every member of the Holy Trinity: The Father judges through the Son, the Holy Spirit shows mercy and heals the wounds of sin and the wounds of creation [...] The Holy Spirit, the Comforter heals wounded creation and shows it God's mercy. We see here a religious antinomy of judgement and mercy, which is a witness of God's providence" (Bulgakov, 1992, pg. 201).

Deification is, thanks to the grace of the Holy Spirit, the highest state of the spirit, to which all people are called, and participation in the eternal existence of God. The role of the Holy Spirit, as St. Maximus the Confessor claims, is man's internal orientation towards the way of making oneself like God (1 Jn 3:2) (Alfeyev, 2009, pg. 248-249). However, deification is not a transformation into the essence of God, but a participation in Divine brightness (St. John of Damascus, 1969, pg. 95). In contrast to the Neo-platonic vision of dissolving into One, Christian deification does not lead to a loss of one's own individuality. Deification "means the highest unity with Divine light and participation in God's energies without losing one's own personality, a common bond and co-penetration of God and man as two people, who become 'equal"' (Alfeyev, 2009, pg. 250) St. Symeon the New Theologian, when comparing people 
to hay and God to fire, finally states: "you keep the material of hay resistant to the activity of the fire and preserving it unchanging, you transform it all so that the hay is light, but light is not hay? And you join hay with Light, without mixture, and the hay becomes light, changing itself without changing" (quote from Alfeyev, 2009, 252-253). Evdomikov supplements these statements about the character of the activity of the Holy Spirit by indicating His dynamic (Evdomikov, 1964, pg. 267).

The deification of man leads to a change of heart. St. Isaac the Syrian, the most experienced Eastern Christian guide in asceticism, wrote long before the concept of Hesychasm wrote about this. He described the most important grace of the Holy Spirit as "a loving heart" (Osipov, 2011, pg. 202).

When pointing out the relation of the Holy Spirit with man, Orthodoxy does not accept the idea of changing the hypostasis of human nature: "Human nature ontologically remains, finding its basis in the hypostasis of Christ, but becomes sanctified and enlightened by the Divine energy thanks to the dynamism of the Holy Spirit" (Evdomikov, 1964, pg. 267). The operation of the Holy Spirit, as an "external" activity is not, as St. John Chrysostom writes, only a "deposit," but a full participation, which is realized on the basis of perichoresis (Evdomikov, 1964, pg. 267).

Among others, St. Seraphim of Sarov, describes the effect of this participation on the basis of perichoresis. In his conversation with Motovilov, he points out the fruit of the grace of the Holy Spirit outlined in the New Testament: joy, love and peace (Gal 5:22). He further states: "When the Spirit of God descends on a person and shades him with the fullness of His descent, then the human soul is filled with unspeakable joy [...]. The Lord Jesus said: The Kingdom of God is in us. Jesus understood the Kingdom of God as the grace of the Holy Spirit" (St. Seraphim of Sarov, 2008, pg. 88-90).

\section{Conclusion}

The gift of the grace of Holy Spirit's kenosis and His role in Orthodox theology is a deifying gift. It is a gift for all of God's people, which the Evangelist Luke clearly states (Acts 2:4). Furthermore, "the gift or charisma of the Spirit are not given exclusively to bishops and priests, but to every baptised person" (Ware, 1999, pg. 101).

This gift is an individual gift, working from "within" and is also a gift of unity, but not of uniformity," which the Kontakion of Pentecost reminds us while making reference to the biblical event of the Tower of Babel and Day of the Descent of the Holy Spirit: "When the Most High came down and confused the tongues, he divided the nations. But when he distributed the tongues of fire, he called all to unity" (quoted in Ware, 1999, pg. 101). The gift of the Spirit allowed for unity despite diversity. The kenotic gift of transforms man and allows him to know God through His uncreated energies. Grace becomes a means to know grace, and by that knowledge of God and communion with Him.

\section{Bibliography}

Afanasyev, M. (2002). Kościół Ducha Świętego. (H. Paprocki, Trans.). Białystok: Bractwo Młodzieży Prawosławnej w Polsce.

Alfeyev, H. (2009). Misterium wiary. Wprowadzenie do prawosławnej teologii dogmatycznej. (J. Charkiewicz, Trans.). Warszawa: Warszawska Metropolia Prawosławna.

Boska Liturgia świętego ojca naszego Jana Chryzostoma. (2001). Warszawa: Warszawska Metropolia Prawosławna.

Bulgakov, S. (1992). Prawosławie. Zarys nauki Kościoła prawosławnego. (H. Paprocki, Trans). Warszawa, Białystok.

Evdokimov, P. (1964). Prawosławie. Warszawa.

Leśniewski, K. (2014). Antropologia w pismach współczesnych teologów prawosławnych. Elpis, (12), 71-95.

Lossky, V. (1983). The Vision of God. Crestwood, New York: SVS Press.

Ławreszuk, M. (2014a). Interpolacje w epiklezach bizantyjskich anafor św. Jana Chryzostoma i św. Bazylego Wielkiego. Elpis, $16,33-41$.

Ławreszuk, M. (2014b). Modlitwa wspólnoty. Historyczny rozwój prawosławnej tradycji liturgicznej. Białystok: Wydawnictwo Uniwersytetu w Białymstoku.

Łosski, W. (1989). Teologia mistyczna Kościoła Wschodniego. Warszawa: PAX.
Osipow, A. (2011). Droga rozumu w poszukiwaniu prawdy. Teologia zasadnicza. (H. Paprocki, Trans.). Warszawa: Warszawska Metropolia Prawosławna.

Paprocki, H. (2012). Zarys prawosławnej nauki o Duchu Świętym. Elpis, 14(25-26), 11-39.

Schmemann, A. (2000). Of Water and the Spirit. A Liturgical Study of Baptism. Crestwood, New York: St Vladimir's Seminary Press.

St. John of Damascus. (1969). Wykład wiary prawdziwej. (B. Wojkowski, Trans.). Warszawa.

St. Serafim of Sarov. (2008). Ogień Ducha Świętego. (H. Paprocki, Trans.). Kraków.

The Holy Bible, New Revised Standard Version. Nashville, Tennessee.

Wagner, G. (1974). Der Heilige Geist als offenbarmachende und vollende Kraft. Das Zeugnist der orthodoxen Tradition. [w:] Erfahrung und Theologie des Heiligest Geistes. Kösel.

Ware, K. (1999). Prawosławna droga. (Siostra Nikolaia, Tłum.). Białystok: Bractwo Młodzieży Prawosławnej w Polsce.

Алымов, В. (b.d.). Лекции по Исторической Литургике (mаszynopis.). Holy Trinity Orthodox School. 